This PDF is a selection from a published volume from the National Bureau of Economic Research

Volume Title: The Economic Consequences of Demographic Change in East Asia, NBER-EASE Volume 19

Volume Author/Editor: Takatoshi Ito and Andrew Rose, editors

Volume Publisher: University of Chicago Press

Volume ISBN: 0-226-38685-6

ISBN13: 978-0-226-38685-0

Volume URL: http://www.nber.org/books/ito_08-2

Conference Date: June 19-21, 2008

Publication Date: August 2010

Chapter Title: The Effects of Demographic Change on Public Education in Japan

Chapter Authors: Fumio Ohtake, Shinpei Sano

Chapter URL: http://www.nber.org/chapters/c8169

Chapter pages in book: (193 - 219) 


\title{
The Effects of Demographic Change on Public Education in Japan
}

\author{
Fumio Ohtake and Shinpei Sano
}

\subsection{Introduction}

Many developed countries are experiencing the population aging. Japan is one of the countries experiencing such aging at the most rapid pace. According to the Japanese census, the percentage of elderly over the age of sixty-five increased to 17.3 percent in 2000 from 7.1 percent in 1970. Furthermore, the Institute for Social Security and Population Research estimated that the ratio would reach 31.8 percent in 2030 .

How does population aging affect the structure of government expenditure? Median voter theory indicates that the preference of the median voter determines the size of government expenditure. If the elderly become median voters, government expenditure such as social security and medical services, which is directly related to the elderly, will be increased. On the other hand, government expenditure such as education, which is not directly related to the elderly, will be decreased by the aging of median voters. In particular, the local governments in Japan will be affected by this problem since the share of their expenditure on education as well as medical and social welfare is high. Thus, it is expected that the government expenditure on education will be decreased by the increase in the share of the elderly in the population.

However, the elderly may support the government's decision to increase

Fumio Ohtake is a professor at the Institute of Social and Economic Research, Osaka University. Shinpei Sano is an assistant professor at the Graduate School of Economics, Kobe University.

The authors thank Takatoshi Ito, Daeil Kim, Ronald Lee, Chang-Gyun Park, Andrew Rose, and an anonymous referee for invaluable comments and suggestions. We also thank Atsushi Morimoto for excellent research assistance. 
expenditure on education. Poterba $(1997,1998)$ pointed out several possibilities. First, the elderly may have a long time horizon with regard to decision making and voting. Expenditure on education is beneficial to the old as well as the young generations in the long run, because monetary transfer from the young to the old generations may be increased by the growth in productivity caused by the increase in educational investment.

Second, the elderly may have an altruistic preference. The utility of the elderly will be increased by the increase in investment on education to their grandchildren or by the increase in consumption of their grandchildren by productivity growth caused by investment on education if they have an altruistic preference toward their children.

Third, an increase in government expenditure on education may indirectly benefit the elderly. The increase in expenditure on education by a local government may raise the land prices in that area because the quality of education would be higher in that area. If most of the elderly own real estate, they would benefit from the increase in land prices. Moreover, the elderly may benefit by the reduction in the crime rate caused by the socialization effects of better education.

Fourth, Tiebout sorting (voting by foot) also affects the relationship between population aging and education expenditure by the government. If a local government imposes higher taxes for better education, the elderly who oppose the increase in taxes would shift to other areas. In this sense, the share of the elderly and education expenditure in the local area are simultaneously determined. Thus, the effects of aging on the change in government expenditure on compulsory education can be regarded as an empirical problem.

Although issues on education have recently attracted public attention in Japan, most of the discussions are not based on empirical research. It is important to analyze the effects of population aging on public expenditure on compulsory education in order to discuss the role of the government in providing education. In particular, this analysis is important in Japan because Japan is the most rapidly aging society. Figure 6.1 shows the time series change in the ratio of people over the age of sixty-five in selected countries. Among the developed countries, although the ratio of the elderly in Japan was relatively low in the 1980s, it rapidly increased from the late 1980s to the 1990s. In 2000, the ratio of the elderly in Japan was the highest among four countries. It is expected that Japanese society will face a higher rate of population aging in the future.

Citing the results of Hoxby (1998), Poterba (1998) pointed that the correlation between the ratio of the elderly and government education expenditure, which was positive in the early 1900s, has recently become negative. However, Poterba (1998) did not empirically test the hypothesis and merely speculated that this change in the sign of the relationship had been caused by the increase in nuclear families. 


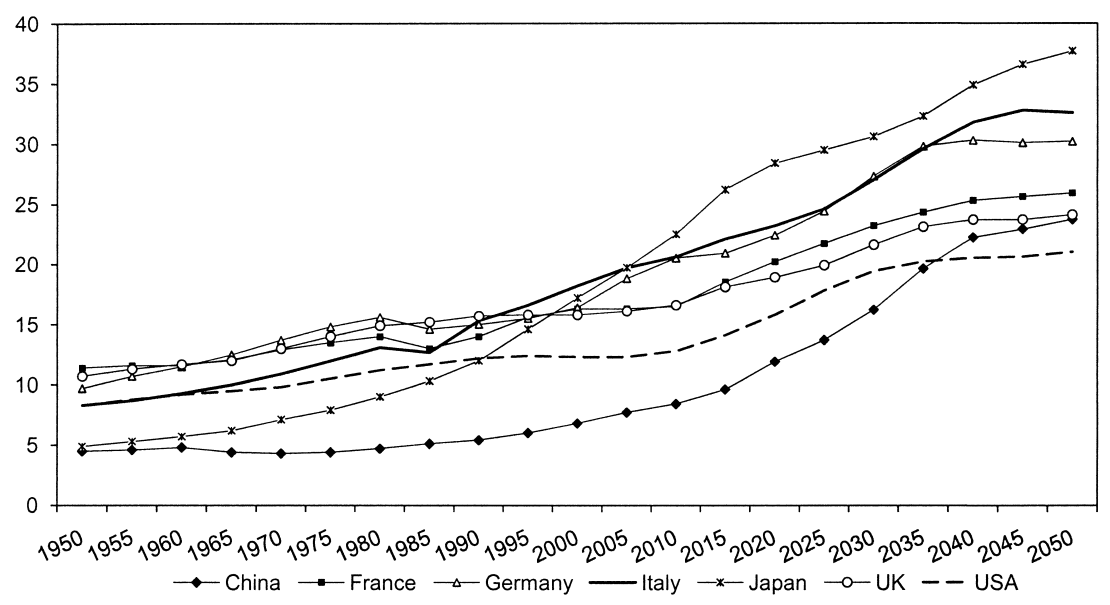

Fig. 6.1 Share of people at the age of sixty-five and over in selected countries

Source: "Population Statistics 2007," National Institute of Population and Social Security Research.

Japan is an ideal testing field for conducting empirical research on the relationship between population aging and public education expenditure. This is because the country recently experienced rapid population aging and a drastic change in household structures - namely, from extended families to nuclear families.

In this chapter, we analyze the effects of population aging on the public expenditure on compulsory education using prefectural panel data from 1975 to 2005 in Japan. The results of the chapter are summarized as follows. The higher ratio of the elderly increased the per-student public expenditure on compulsory education before the 1980s; however, it decreased the per-student public expenditure on compulsory education after the 1990s. Since the elderly began to live independently from their children who are old enough to receive compulsory education, they may have become less concerned about public expenditure on compulsory education. However, the reversal cannot be explained by the change in the living arrangements of the elderly in our analysis. We speculate that the change was caused by the change in the subsidy system on compulsory education from the national government to the local governments.

This chapter is structured as follows. In section 6.2 we review previous research. In section 6.3 we describe the estimation models and the data for empirical analysis. The estimation results and the explanation that the aging population had different effects on the expenditure on compulsory education between the 1980s and the 1990s are presented in section 6.4. In section 6.5 we examine the effects of the changes in the living arrangements of the elderly on the level of public expenditure on compulsory education 
both in the 1980s and 1990s. In section 6.6 we summarize the results and note the problems for future research.

\subsection{Previous Research}

First, we review the theoretical background on the relationship between population aging and the size of government expenditure on compulsory education. According to the median voter theory, the size of government expenditure is determined by the preference of median voters. Person and Tabellini (2000) and Gradstein, Justman, and Meier (2005) show that the preference for public expenditure on the education of voters should be single-peaked with income for the existence of a voting equilibrium. Intuitively, this condition implies that the demand for public expenditure on education monotonically increases with an increase in income (Oberndorfer and Steiner 2006). The aging of median voters increases the public expenditure on goods and services that are demanded by the elderly. If the elderly do not wish to support an increase in public expenditure on compulsory education, population aging decreases the government expenditure on education. ${ }^{1}$

Poterba $(1997,1998)$ pointed out the possibility of a positive correlation between the size of public expenditure on compulsory education and population aging. The elderly support the increase in government expenditure on compulsory education if they are altruistic toward the younger generation or if they are indirectly benefited by the appreciation of land prices, reduction in the crime rate, and increase in future productivity owing to an increase in the expenditure on compulsory education. Thus, because of theoretical ambiguity, the relationship between population aging and expenditure on compulsory education is an empirical problem.

In Europe and the United States, empirical research on the relationship between population aging and government expenditure on compulsory education has been accumulated. Poterba $(1997,1998)$ analyzed the impact of population aging on government expenditure on compulsory education (K through 12) using state-level panel data from 1961 to 1991 in the United States. According to his estimation results, a 1 percent increase in the ratio of the elderly — aged at least sixty-five years - reduces the per-student public expenditure on education by about 0.26 percent.

Harris, Evans, and Schwab (2001) estimated the relation using school

1. Even parents of school-age kids would be against public expenditure if the private sector can do it better. This might be true for high income parents who send their kids to private school. However, the percentage of pupils in private school in compulsory education is very low in Japan. Of elementary school pupils, 99.0 percent went to public school and of junior high school students, 93.5 percent went to public school in 2004. Sugimoto and Nakagawa (2007) argued the role of public education on fertility during the industrialized process. They demonstrated the vicious cycle between population aging and the undersupply of public education in advanced economies. 
district-level data for 1972, 1982, and 1992 because the population structure and education expenditure changed in school districts even if they were located in the same state. The estimated negative effects of the ratio of the elderly on education expenditure are smaller than those obtained by Poterba - there is a negative correlation between population aging and education expenditure.

Ladd and Murray (2001) conducted research using the county-level data for 1970, 1980, and 1990 in the United States. Their results reveal that the impact of the ratio of the elderly on education expenditure by the government is not statistically significant.

Using individual cross-section data, Rubinfeld (1977) indicated that the elderly do not tend to vote for policies that increase the expenditure on education. Based on household data, Brunner and Balsdon (2004) examined whether respondents agree with hypothetical educational policies at the national and regional levels. They reveal that the elderly tend to support an increase in government expenditure on education at the regional rather than the national level. However, they do not identify the reason for the preference of the elderly for local government education expenditure-whether the elderly wish to raise the local land price or if they have an altruistic preference toward the young generation.

Using the state-level data from 1990 to 2002 in Switzerland, Grob and Wolter (2005) found that an increase in the ratio of the elderly (retired) decreases the per-student expenditure on compulsory education (elementary and junior high school). They also showed that the effects of the decrease in public expenditure on education caused by the increase in the ratio of the elderly are greater than those caused by the decrease in the number of students. ${ }^{2}$

By contrast, no study has been conducted on the relationship between population aging and government expenditure on education in Japan. Although Doi (1998a, 1998b) empirically examined the median voting theory using Japanese data, he analyzed the determinants of the size of overall public expenditure rather than categorizing public expenditure such as education.

This chapter is the first attempt to examine the effects of aging on government expenditure on education in Japan. Japan is an ideal testing field for analyzing this problem because it has experienced a rapid change in both population and household structures in the last three decades.

Hoxby (1998) indicated a positive correlation between the ratio of the elderly and government expenditure in the early 1900s in the United States. She also revealed that the correlation gradually changed from positive to

2. Oberndorfer and Steiner (2006) examined the effects of political variables on higher education in Germany. They found that leftist governments increase education expenditure. 
negative in the nineteenth century. Goldin and Katz (1998) showed the same change of correlation between population aging and public expenditure on higher education.

Poterba (1998) conjectured that the change of correlation between the elderly and public expenditure on education was caused by the trend toward nuclear families, although he did not empirically examine the hypothesis.

Because there is a growing trend toward nuclear families in the last three decades in Japan as well as a rapid increase in the ratio of the elderly, we are able to test the effects of population aging as well as the change in the household structure on public expenditure on education.

\subsection{Empirical Analysis}

\subsubsection{The Fiscal System of Public Education in Japan}

In Japan, there is a substantial variation in the per-student government expenditure on compulsory education among local governments because the cost of compulsory education is borne both by the central and local governments. The subsidy system from the national government to local governments for the costs of compulsory education is as follows.

The number of classes and teachers are determined by the Compulsory Education Standards Law. The law stipulates the maximum number of students per class as forty from 1998 (forty-five from 1968 to 1997). The national treasury burdens of compulsory education costs subsidizes local governments for the half the cost of the compensations for teachers including lump sum retirement allowance, mutual aid benefit (social security benefit for teachers), travel expenses, and education materials if the number of teachers is determined by the Compulsory Education Standards Law. After the introduction of this subsidy system in 1952, the Japanese government increased the amount of subsidy to local governments for compulsory education costs in order to equalize the national level of the quality of education. The Japanese government's equalization policy for the quality of education changed the relationship between per pupil education costs and the financial capability of the local government. According to Kariya (2006), a positive correlation existed between the per pupil costs of public elementary school and the financial capability index of the local governments in 1965; however, this correlation changed to negative in 2003.

From 1985, the subsidy for compensation for teachers has been gradually reduced. In 1985, the Japanese government discontinued subsidies to the local governments for the costs of education material and travel expenses. From 1986, the subsidies for the costs of social security benefits and the lump sum retirement allowance for teachers have been gradually reduced. The subsidy for the costs of lump sum retirement allowance was abolished in 1993, and the subsidy for the costs of social security benefits for teachers 
was abolished in 2003. From 2006, the subsidy for the salary of teachers from the national government to local governments was reduced from one-half to one-third of the total salary of the teachers.

At the same time, the discretionary power of local governments on compulsory education has been increased. Until 2003, the local governments were not able to reduce the class size below forty students per class. Although this restriction was lifted in 2003, the national government did not subsidize the salaries of teachers that exceeded the standard number of teachers determined by the standard class size of forty pupils.

Prefectural governments have discretionary power on hiring of teachers. Municipal governments were not able to hire full-time teachers for municipal elementary and junior high schools by their own financial resources because the prefectural boards of education appointed teachers for municipal schools and prefectures bore the salary for the teachers of municipal schools. ${ }^{3}$ Except for the hiring of the teachers, municipal governments can determine the size of expenditure on educational costs such as costs for educational materials, libraries, and travel in municipal schools from $1985 .{ }^{4}$

There are large differentials between standard financial needs for compulsory education - which determine the size of the local allocation tax grant for prefectures - and actual expenditure on the compulsory education by the prefectures. For example, the maximum value of the ratio of actual expenditure on educational materials for compulsory schools to the standard financial needs in the local allocation tax grant for prefectures was 163.7 percent in Tokyo and the minimum value of the ratio was 35.6 percent in Tokushima in 2003 (the average value was 75.7 percent).

As shown in figure 6.2, the subsidies for local governments on compulsory education had decreased in the 1980s and had been stable in the 1990s. On the contrary, by 1995, the expenditure of local governments on compulsory education continued to increase. Figure 6.3 shows the change in the educational costs per pupil by the national and local governments. From 1985, the per-student educational costs by local governments has been increasing. However, the subsidy from the national government gradually increased in the same period.

These changes in the fiscal system of compulsory education in Japan might have affected the expenditure of local governments on public education. As local governments increased the discretional power for determining the expenditure on compulsory education, the level of education costs was determined by political pressure.

3. This regulation was relaxed in the special zone for structural reform from 2002 .

4. Although municipal level analysis would be desirable if municipal level data were available, we were not able to get municipal level data in this analysis. Thus, we use prefectural level data in this chapter. Prefectural level analysis can be justified because the share of labor cost is very high (about 75 percent from 1997 to 2005) in educational expenditure. 


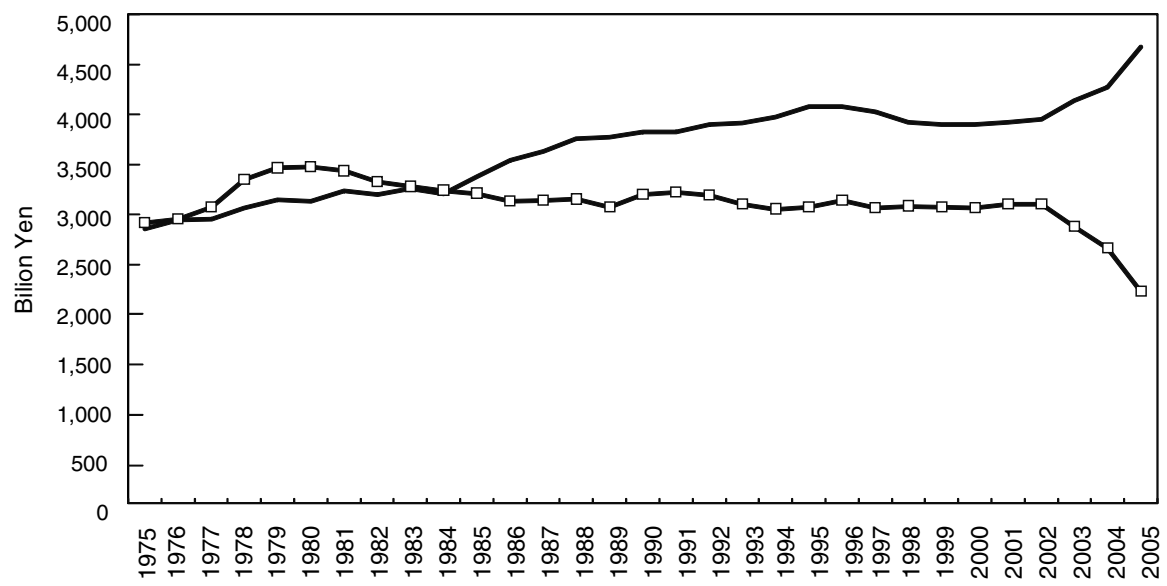

-Educational Expense by Local Governments $\quad \rightarrow-$ National Burden for Educational Expense

Fig. 6.2 Total expenditure on compulsory education by national and local governments Note: Deflated by CPI in 2000.

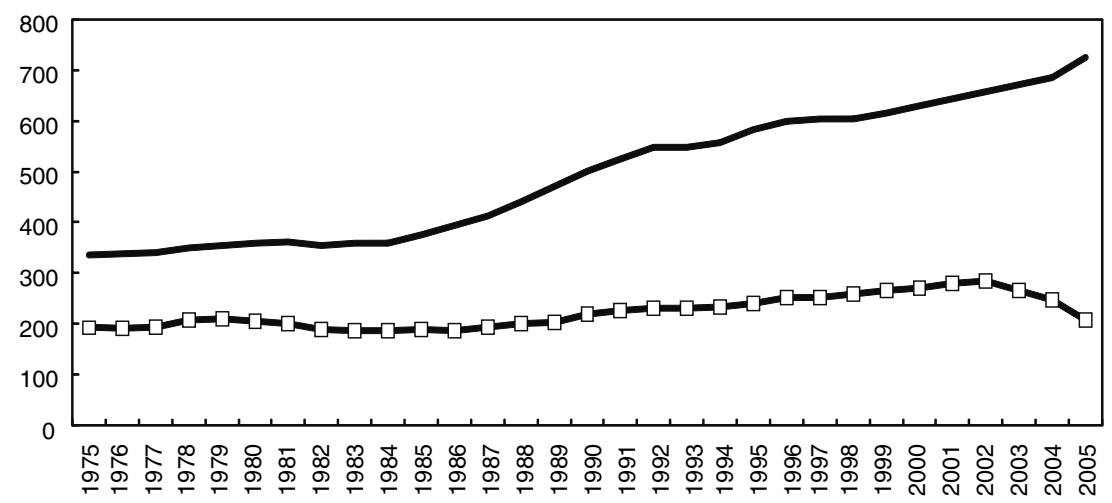

- Per pupil educational expense by local governments
- Per pupil educational subsidy by national governments

Fig. 6.3 Per pupil educational expense by national and local governments Note: Deflated by CPI in 2000.

\subsubsection{Estimation Model}

Similar to Poterba $(1997,1998)$, we estimate the following model to test the effects of population aging.

$$
\begin{aligned}
E d u c_{i t}= & \beta_{1} \text { OLD }_{i t}+\beta_{2} \mathrm{KID}_{i t}+\beta_{3} \text { Income }_{i t}+\beta_{4} \mathrm{Aid}_{i t} \\
& +\beta_{5} \text { Unemp }_{i t}+\beta_{6} \text { House }_{i t}+\beta_{7} \operatorname{Urban}_{i t}+u_{i t} \\
u_{i t}= & \tau_{t}+\alpha_{i}+\varepsilon_{i t} .
\end{aligned}
$$


The subscripts $i$ and $t$ stand for prefecture and time, respectively. Variable Educ $_{i t}$ represents the per student compulsory education costs of prefecture $i$ at time $t$. Similarly, OLD is the percentage of the elderly who are sixty-five years of age or above, and KID is the percentage of people old enough to receive compulsory school education in prefecture $i$ at time $t$. These variables capture the demographic effects on public education costs.

In order to control for the effects of the subsidy from the central government, we added the per-student subsidy from the central government to the local government (Aid) to the estimation model. Variable House is the house ownership rate and it controls for the difference in the preference with regard to public expenditure on education between households with and without ownership of their houses. Variable Income is the per capita prefectural income; Unemp, the unemployment rate; and Urban, the percentage of people who live in urban areas. These variables capture the information on the income distribution of the prefectures. Variable $u_{i t}$ is the error term and it is assumed that the error term is decomposed to time effect $\left(\tau_{t}\right)$, prefecture fixed effect $\left(\alpha_{i}\right)$, and the idiosyncratic error $\left(\varepsilon_{i t}\right)$, with mean 0 and constant variance.

We are most interested in the coefficient of OLD in the estimation. If this coefficient is negative, we can interpret the situation as follows: the elderly support policies that directly benefit them because of their self-interest. On the other hand, if the coefficient of OLD is positive, we interpret the situation as follows: the elderly support the increase in public education either because they recognize the benefit of public education - since they are altruistic or long-term decision makers-or because their welfare will be raised by the decrease in crime rate and increase of land prices. However, we cannot identify the reasons that the elderly support the increase of public expenditure on compulsory education when the coefficient of OLD is positive in the estimation.

Let us discuss the other explanatory variables. The coefficient of KID is expected to be negative because the per-student public education costs would be reduced by an increase in the per capita number of children if the total government expenditure on education does not increase along with the number of children. The coefficient of House is expected to be positive because homeowners will benefit from the increase in land prices due to an increase in the quality of education. The coefficient of Income is expected to be positive since a higher income household would demand a higher level of education. The coefficient of Unemp is expected to be negative because people may prefer the strengthening of measures for unemployment to increasing the education quality when the unemployment rate is high. Variable Urban is expected to have a negative coefficient since people living in urban areas, where private schools are located, may prefer private schools to public ones.

We use the panel estimation method with prefectural fixed effects. This estimation method provides a consistent estimator when the unobserved 
prefectural factors are correlated with both education costs and demographic change.

Harris, Evans, and Schwab (2001) and Ladd and Murray (2001) pointed out that the ratio of the elderly might be endogenously determined. Under Tiebout sorting, if the elderly are self-interested, they may shift from the high-quality education area because of higher taxes. In this case, the estimated coefficients by ordinary least squares (OLS) are biased because the expenditure on compulsory education and the ratio of the elderly are simultaneously determined. To avoid this bias, we use the ratio of the elderly five years ago as an instrumental variable (IV). This variable is adequate as an IV because we can consider that the ratio of the elderly five years ago is independent from the current level of government expenditure on education. ${ }^{5}$

\subsubsection{Data}

We use prefectural panel data from 1975 to 2005 to estimate the model. Since we use the census survey that is conducted every five years, we use the prefectural panel data with a five-year interval. The definitions and sources of the data are as follows.

The amount of government expenditure on compulsory education is obtained from the "Survey of the Educational Costs by the Local Governments" (Ministry of Education, Culture, Sports, Science, and Technology [MEXT]). The costs include the expenditures on elementary and junior high schools paid by prefectures and municipalities. The numbers of students are obtained from the "Basic Survey on Schools" (MEXT). The per-student education costs are obtained by dividing the total expenditure on compulsory education by the number of students.

The ratio of the elderly aged sixty-five years or above (OLD) and the ratio of young people aged between five and fourteen years (KID) are calculated from "the Population Census" (Ministry of Internal Affairs and Communications $[\mathrm{MIC}])$.

The per-student subsidy from the central government (Aid) is the amount of subsidy for compulsory education from the central government divided by the number of students ("Survey of the Educational Costs by the Local Governments").

The per capita prefectural income (Income) is the prefectural income ("Annual Report on Prefectural Accounts" [Cabinet Office]) divided by the prefectural population. The Prefectural Unemployment rates (Unemp) are calculated from the Population Census.

The house ownership rate (House) is taken from "The Housing and Land Survey" (MIC). This survey was conducted two years before the Population Census, which we use for the other variables. We use the ratio of population

5. Harris, Evans, and Schwab (2001) and Ladd and Murray (2001) reported that the estimation results by OLS and IV are similar. 
in a densely inhabited district from the Population Census for the proxy of the degree of urbanization. We realized monetary variables by the consumer price index (CPI) in 2000. Since all the variables are logarithmically transformed, as in the previous research, the estimated coefficient implies elasticity. Table 6.1 shows the descriptive statistics of the variables.

Figure 6.4 shows the scatter plot between the per-student education costs (Educ) and the ratio of the elderly aged sixty-five years or above (OLD). Although there is positive correlation between Educ and OLD, this correlation might be caused by the other variables. For example, the prefectures that have a higher ratio of young people aged between five and fourteen years (KID) show the higher Educ because there is scale economy due to fixed costs in educational expenditure, as shown in figure 6.5.

Table 6.1

Descriptive statistics

\begin{tabular}{lcrrrr}
\hline & & & Standard \\
Variable & Observations & Mean & Min & Max \\
\hline & $1975-2005$ & & & & \\
Per-pupil local educational expenditure & 329 & 499.43 & 152.91 & 267.74 & 930.95 \\
Population share of old (\%) & 329 & 14.53 & 5.00 & 5.27 & 27.09 \\
Population share of kid (\%) & 329 & 13.11 & 2.60 & 7.54 & 20.55 \\
$\quad$ Per-pupil subsidy & 329 & $2,525.79$ & 555.96 & $1,484.60$ & $4,884.71$ \\
Per capita income & 329 & 235.27 & 42.77 & 147.62 & 377.58 \\
Unemployment rate (\%) & 329 & 3.64 & 1.64 & 1.23 & 11.85 \\
House occupation rate (\%) & 329 & 67.83 & 8.89 & 39.44 & 85.73 \\
Population density index & 329 & 47.75 & 18.61 & 21.85 & 98.03 \\
& $1975-1985$ & & & & \\
Per-pupil local educational expenditure & 141 & 358.29 & 40.14 & 267.74 & 547.24 \\
Population share of old (\%) & 141 & 10.29 & 2.10 & 5.27 & 15.32 \\
Population share of kid (\%) & 141 & 15.60 & 1.10 & 12.72 & 20.55 \\
Per-pupil subsidy & 141 & $2,078.50$ & 351.43 & $1,484.60$ & $3,743.86$ \\
Per capita income & 141 & 215.40 & 34.50 & 147.62 & 298.64 \\
Unemployment rate (\%) & 141 & 2.70 & 1.17 & 1.23 & 8.09 \\
House occupation rate (\%) & 141 & 68.66 & 9.76 & 39.44 & 85.73 \\
Population density index & 141 & 44.74 & 18.31 & 21.85 & 97.21 \\
& $1990-2005$ & & & & \\
Per-pupil local educational expenditure & 188 & 605.27 & 116.29 & 411.65 & 930.95 \\
Population share of old (\%) & 188 & 17.71 & 4.10 & 8.28 & 27.09 \\
Population share of kid (\%) & 188 & 11.24 & 1.66 & 7.54 & 16.93 \\
Per-pupil subsidy & 188 & $2,861.26$ & 430.92 & $2,066.31$ & $4,884.71$ \\
Per capita income & 188 & 250.17 & 42.38 & 171.84 & 377.58 \\
Unemployment rate (\%) & 188 & 4.36 & 1.59 & 1.73 & 11.85 \\
House occupation rate (\%) & 188 & 67.21 & 8.16 & 39.59 & 84.88 \\
Population density index & 188 & 50.01 & 18.56 & 24.16 & 98.03 \\
\hline
\end{tabular}

Source: "The Population Census" (Ministry of Internal Affairs and Communications). 


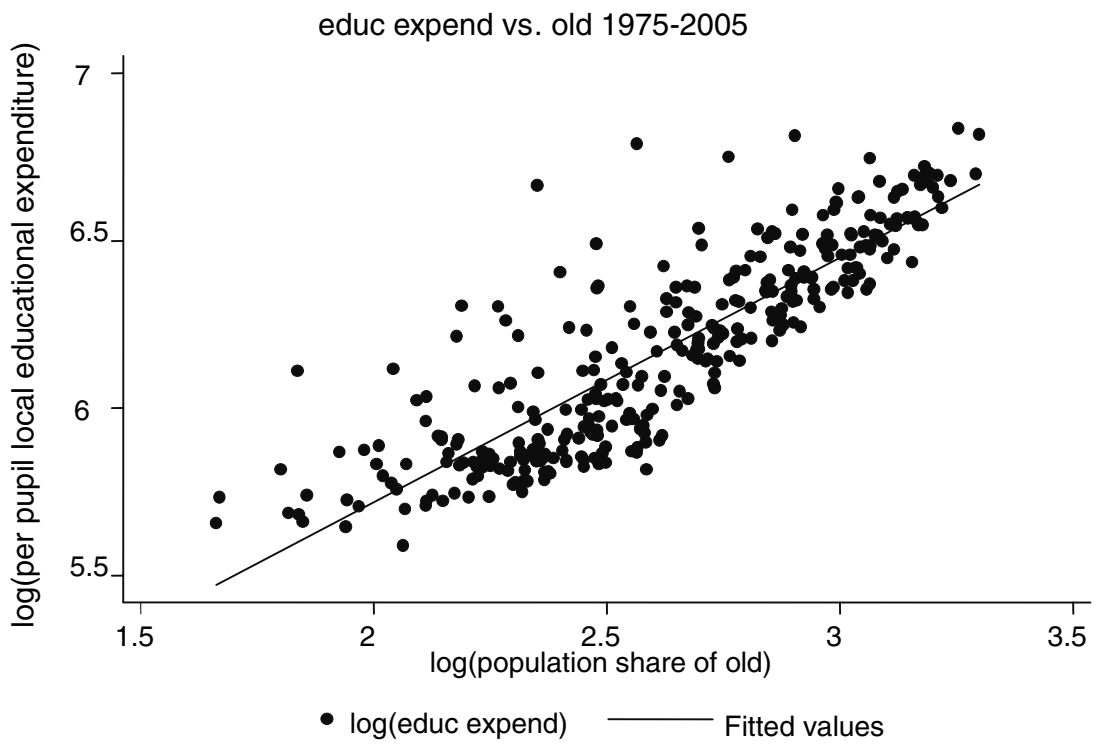

Fig. 6.4 Scatter plot between Educ and OLD

Note: This figure plots the relationship between the per-student education costs (Educ) and the ratio of the elderly aged sixty-five years or above (OLD) from 1975 to 2005.

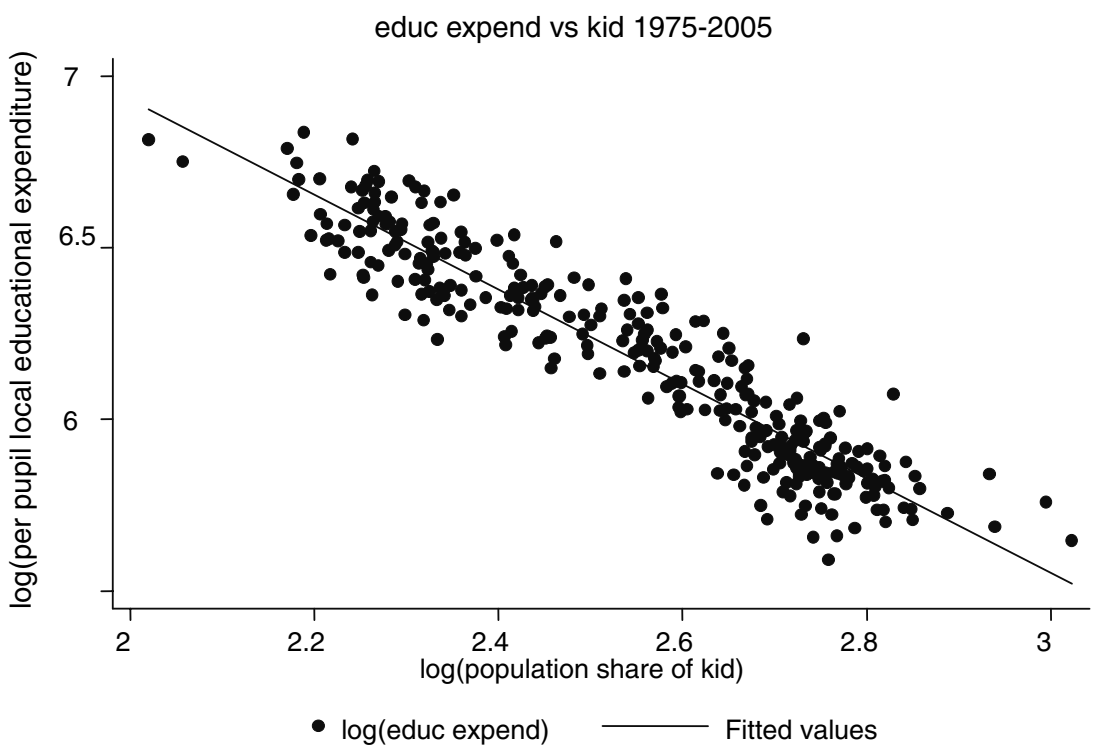

Fig. 6.5 Scatter plot between Educ and KID

Note: This figure plots the relationship between the per-student education costs (Educ) and the ratio of young people aged between five and fourteen years (KID) from 1975 to 2005. 


\subsection{Estimation Results}

\subsubsection{Base Model}

Let us examine the estimation results of the effects of population aging on the per-student compulsory education costs. Table 6.2 reports the benchmark estimation results. Columns (1) to (3) in table 6.2 show the estimation results by OLS in specifications with and without the variables of unemployment rate and the ratio of population in a densely inhabited district.

The estimated coefficients of the ratio of the elderly by OLS are not statistically significant, although they are positive. However, the estimation results by OLS might be biased if the unobserved fixed effects are correlated with the explanatory variables. In order to check this possibility, we conducted the Breusch-Pagan and Hausman tests. First, the random effect model is supported between OLS and the random effect model by the Breusch-Pagan test. Second, the fixed effect model is supported between the fixed effect model and the random effect model by the Hausman test. Thus, we use the fixed effect model for estimation.

Figures in columns (4) to (6) in table 6.2 report the estimation results by the fixed effect model and show that the percentage of people aged sixtyfive years or above significantly reduces the per-student public education costs.

Let us focus on other variables. The coefficient of the ratio of people below fifteen years of age is significantly negative. This implies that the increase in the ratio of people old enough to receive compulsory school education decreases the per-student compulsory education costs. The coefficient of per capita prefectural income, which denotes the income level of a household, is significantly positive. The amount of per-student subsidy for compulsory schools from the central government has a significant positive effect on the per-student compulsory school costs paid by the local governments. The estimated coefficient of the house ownership rate is significantly negative in the OLS; however, it is not significantly positive in the fixed effect estimation. The unemployment rate is not significant in the fixed effect estimation when we control the ratio of population in a densely inhabited district. The estimated coefficient of the ratio of population in a densely inhabited district is not significantly negative.

As shown in figure 6.1, Japan experienced rapid population aging in the 1990 s, leading to the possibility of structural change in the relationship between population aging and the per-student education costs. Thus, we conducted the Chow test to test the stability of coefficients in the estimation period. Concretely speaking, we conducted the test for the structural change that occurred in the following years - 1980, 1985, 1990, 1995, and 2000. The results are shown in table 6.3. According to this table, the null hypothesis of no structural change is rejected at the 5 percent significance level. We also 


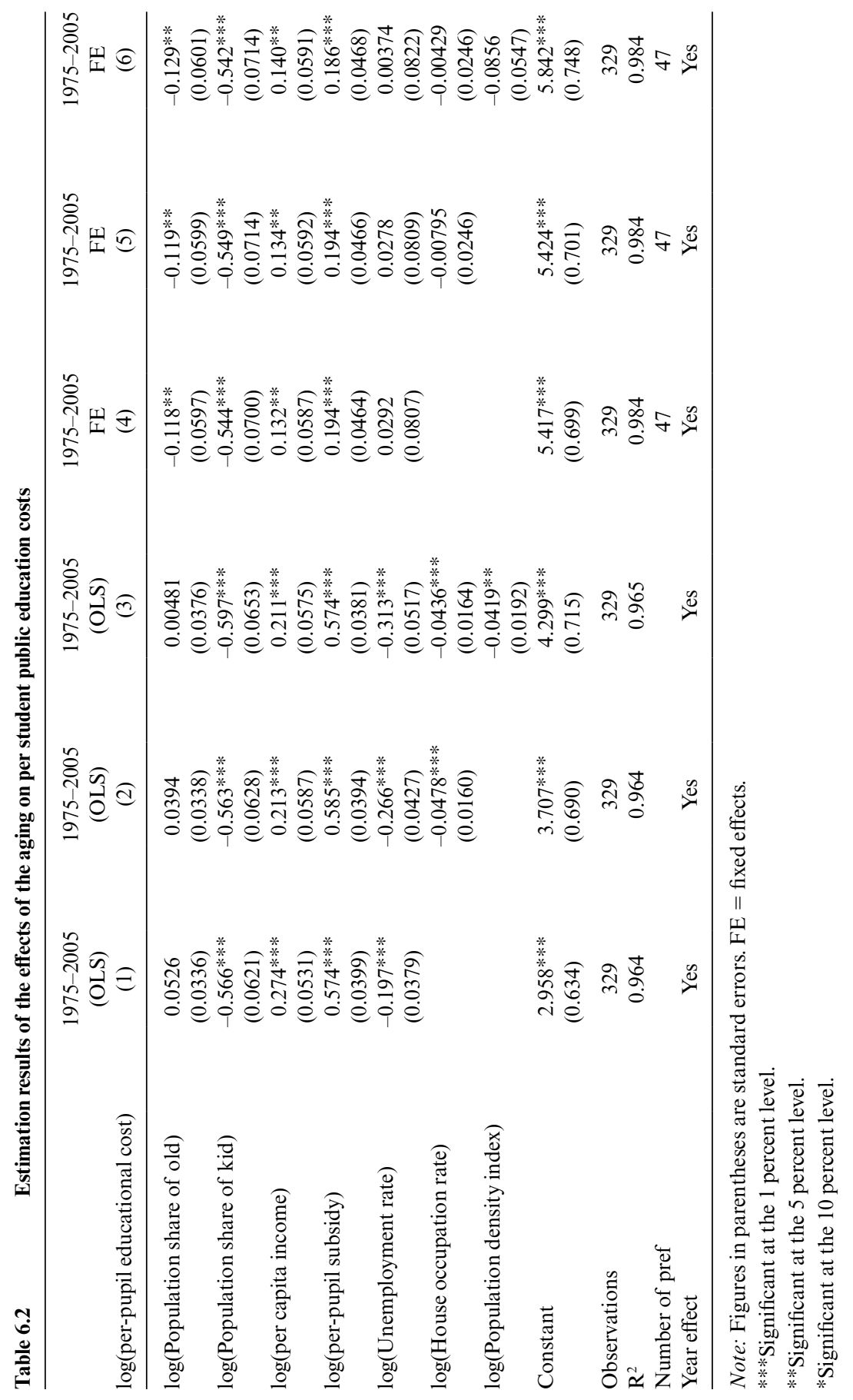


Table 6.3 Tests for structural change

\begin{tabular}{ccc}
\hline Structural break point & $F$-statistics & $P$-value \\
\hline 1980 & 1.06 & 0.39 \\
1985 & 1.73 & 0.08 \\
1990 & 2.09 & 0.03 \\
1995 & 3.35 & $>0.001$ \\
2000 & 4.82 & $>0.001$ \\
\hline
\end{tabular}

Note: The Chow test was used to test the structural change that occurred between the first and second years' statistics.

conducted a sequential test for structural change using the yearly panel data from 1975 to 2005, eliminating those variables that are only available at five-year intervals - for instance, the housing ownership and unemployment rates. In the sequential test for structural change, we test the possibility of structural change for every year. First, we conduct the Chow test to test the structural change that occurred between the first and second years. Second, we examine the change that occurred between the second and third years, and so on. We infer that the structural change occurred in the year that takes the maximum value of $F$ (test statistic). According to appendix figures 6A.1 and 6A.2, which present the results of the sequential tests for structural change (Chow tests and cumulative sum [CUSUM] test, respectively), we can infer that the structural change occurred around 1993. We estimated the model using a separated sample period because the effect of population aging on public education costs may have changed between the 1980s and 1990 s, according to the results of the structural change.

Table 6.4 reports the results of the fixed effect estimation using the separated sample periods - the sample before 1985 and after 1990. Table 6.4 shows that the estimated coefficients of the ratio of the elderly are significantly positive when we use the sample before 1985 . The coefficient changes to significantly negative when we use the sample of the 1990s. The estimated coefficients of other variables do not change between the 1980s and 1990s.

Figure 6.6 plots the relationship between the log of the per-student education costs (Educ) and the ratio of the elderly aged sixty-five years or above (OLD), after adjusting for KID, Aid, Income, Unemp, House, and prefectural fixed effects from 1975 to 2005 . There is negative relationship between Educ and OLD if we adjust other explanatory variables as shown in column (1) of table 6.4. Figures 6.7 and 6.8 are scatter plots for divided samples for 1975 to 1985 and 1990 to 2005, corresponding to columns (2) and (3) of table 6.4. These figures show that the relationship between Educ and OLD changed from negative to positive after 1990. In sum, similar to the case observed by Poterba (1997) in the United States, population aging decreased the per-student compulsory education costs in the 1990s in Japan. 
Table 6.4

Estimation results of the effects of aging on per-student public education costs based on the divided sample periods

\begin{tabular}{lccc}
\hline & $1975-2005$ & $1975-1985$ & $1990-2005$ \\
& FE & FE & FE \\
$\log$ (per-pupil educational cost) & $(1)$ & $(2)$ & $(3)$ \\
\hline $\log$ (Population share of old) & $-0.129^{* *}$ & $0.315^{*}$ & $-0.495^{* * *}$ \\
& $(0.0601)$ & $(0.174)$ & $(0.116)$ \\
$\log$ (Population share of kid) & $-0.542^{* * *}$ & $-0.593^{* * *}$ & $-0.775^{* * *}$ \\
& $(0.0714)$ & $(0.126)$ & $(0.167)$ \\
$\log$ (per capita income) & $0.140^{* *}$ & $0.255^{* *}$ & $0.151^{*}$ \\
& $(0.0591)$ & $(0.112)$ & $(0.0895)$ \\
$\log$ (per-pupil subsidy) & $0.186^{* * *}$ & $0.332^{* * *}$ & $0.124^{* *}$ \\
& $(0.0468)$ & $(0.0972)$ & $(0.0565)$ \\
$\log$ (Unemployment rate) & 0.00374 & 0.212 & -0.0717 \\
& $(0.0822)$ & $(0.133)$ & $(0.197)$ \\
$\log$ (House occupation rate) & -0.00429 & -0.0789 & 0.0255 \\
& $(0.0246)$ & $(0.0581)$ & $(0.0440)$ \\
$\log$ (Population density index) & -0.0856 & -0.0523 & -0.0681 \\
& $(0.0547)$ & $(0.118)$ & $(0.114)$ \\
Constant & $5.842^{* * *}$ & $2.423^{*}$ & $8.527^{* * *}$ \\
& $(0.748)$ & $(1.387)$ & $(1.407)$ \\
Observations & 329 & 141 & 188 \\
Number of pref & 47 & 47 & 47 \\
$R^{2}$ & 0.984 & 0.770 & 0.963 \\
Year effect & Yes & Yes & Yes \\
\hline
\end{tabular}

Notes: Figures in parentheses are standard errors. FE $=$ fixed effects.

***Significant at the 1 percent level.

**Significant at the 5 percent level.

*Significant at the 10 percent level.

\subsubsection{Estimation Results by IV}

If voting by foot works, the elderly would shift from the regions where they have to pay higher taxes to finance higher costs for public education. In this case, the ratio of the elderly and the public education costs are simultaneously determined and the ratio of the elderly should be considered as an endogenous variable in the estimation. Harris, Evans, and Schwab (2001) and Ladd and Murray (2001) used the ratio of the elderly in previous census as an IV for the current ratio of the elderly. Since the current level of government expenditure on compulsory education does not affect the percentage of the elderly five years earlier, the ratio satisfies the conditions of an IV. Therefore, we use the ratio of the elderly five years earlier as an IV. Moreover, we estimate the model using the divided samples of the 1980s and 1990s.

Estimation results by IV are shown in table 6.5. The ratio of the elderly does not have a significant effect on the per-student government expenditure on compulsory education, either in the entire sample period nor in the 


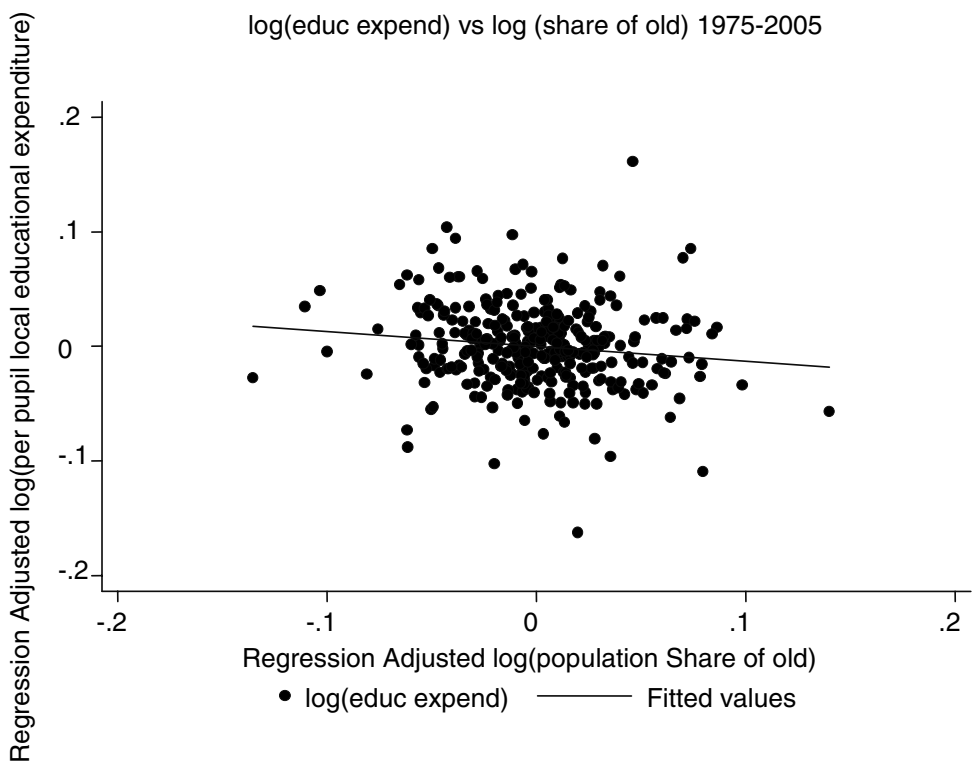

Fig. 6.6 Scatter plot between Educ and OLD after regression adjusted from 1975 to 2005

Note: This figure plots the relationship between the per-student education costs (Educ) and the ratio of the elderly aged sixty-five years or above (OLD), after adjusting for KID, Aid Income, Unemp, House, and prefectural fixed effects from 1975 to 2005.

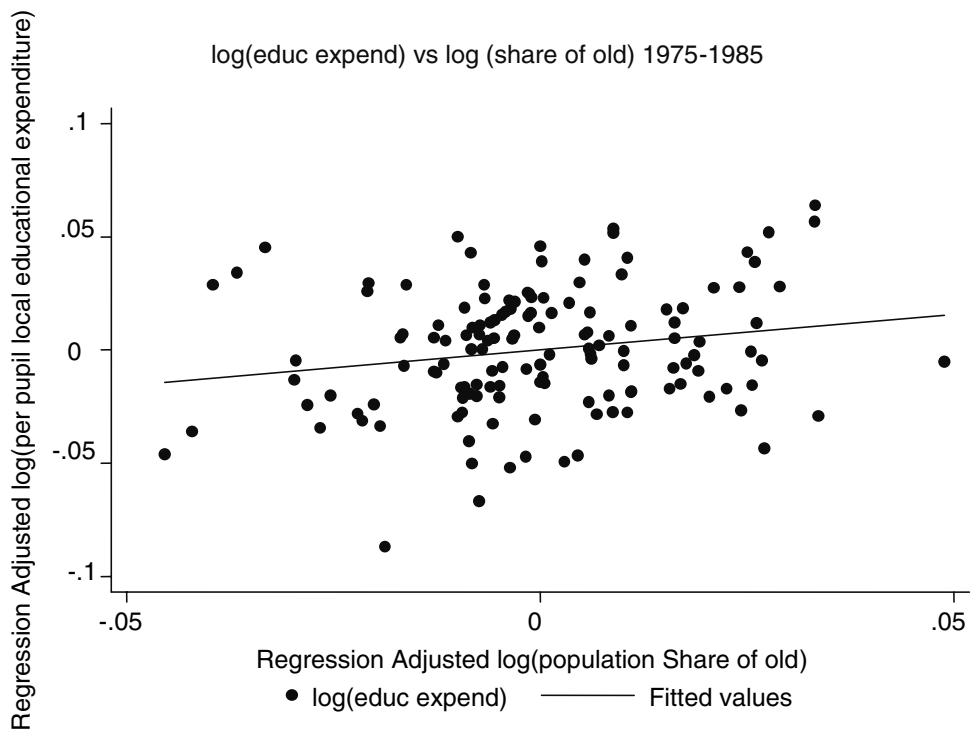

Fig. 6.7 Scatter plot between Educ and OLD after regression adjusted from 1975 to 1985

Note: This figure plots the relationship between the per-student education costs (Educ) and the ratio of the elderly aged sixty-five years or above (OLD), after adjusting for KID, Aid, Income, Unemp, House, and prefectural fixed effects from 1975 to 1985. 


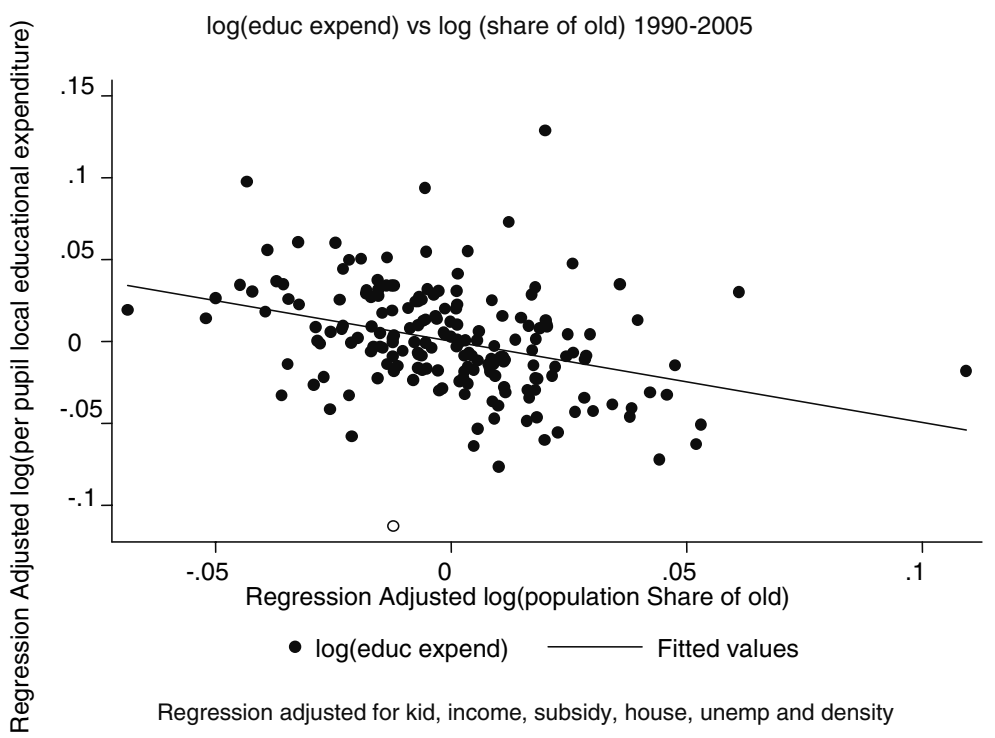

Fig. 6.8 Scatter plot between Educ and OLD after regression adjusted from 1990 to 2005

Note: This figure plots the relationship between the per-student education costs (Educ) and the ratio of the elderly aged sixty-five years or above (OLD), after adjusting for KID, Aid, Income, Unemp, House, and prefectural fixed effects from 1990 to 2005.

1980s. However, similar to the OLS results in table 6.4, the ratio of the elderly significantly decreases the per-student compulsory education costs in the sample of the 1990s when we use the IV method that provides the consistent estimator shown in table 6.5.

These results imply that the elderly in Japan have become self-interested since the 1990s and that population aging decreases the per-student compulsory school costs. The results obtained in Japan in the 1990s are similar to those obtained by Poterba (1997) and Harris, Evans, and Schwab (2001) in the United States and by Grob and Wolter (2005) in Switzerland.

Demographic change has both negative and positive effects on public education costs. The increase in the ratio of the elderly population decreases the per-student public education costs because of political pressure from the elderly. On the other hand, the decrease in the ratio of children old enough to receive compulsory education increases the per-student public education costs because of the adjustment costs for changing the number of teachers and consolidating schools. What are the net effects of the demographic change on public education costs?

According to table 6.5 , the 1 percent increase in the ratio of the elderly decreases the per-student education costs by around 0.6 percent. The 1 per- 
Table 6.5 Estimation results using IV

\begin{tabular}{lccc}
\hline & $1975-2005$ & $1975-1985$ & $1990-2005$ \\
& FEIV & FEIV & FEIV \\
$\log$ (per pupil educational cost) & $(1)$ & $(2)$ & $(3)$ \\
\hline $\log$ (Population share of old) & -0.0421 & 0.321 & $-0.599^{* * *}$ \\
& $(0.0700)$ & $(0.246)$ & $(0.150)$ \\
$\log$ (Population share of kid) & $-0.514^{* * *}$ & $-0.592^{* * *}$ & $-0.795^{* * *}$ \\
& $(0.0725)$ & $(0.128)$ & $(0.169)$ \\
$\log$ (per capita income) & $0.148^{* *}$ & $0.255^{* *}$ & 0.125 \\
& $(0.0595)$ & $(0.112)$ & $(0.0929)$ \\
$\log$ (per pupil subsidy) & $0.192^{* * *}$ & $0.331^{* * *}$ & $0.117^{* *}$ \\
& $(0.0470)$ & $(0.101)$ & $(0.0570)$ \\
$\log ($ Unemployment rate) & -0.0373 & 0.210 & 0.0133 \\
& $(0.0841)$ & $(0.142)$ & $(0.212)$ \\
$\log$ (House occupation rate) & -0.00313 & -0.0794 & 0.0209 \\
& $(0.0247)$ & $(0.0596)$ & $(0.0444)$ \\
$\log$ (Population density index) & -0.0767 & -0.0513 & -0.0746 \\
& $(0.0550)$ & $(0.121)$ & $(0.114)$ \\
Constant & $5.619^{* * *}$ & $2.419^{*}$ & $8.504^{* * *}$ \\
& $(0.756)$ & $(1.393)$ & $(1.428)$ \\
& First stage & & \\
$\log$ (Population share of old 5 yrs ago) & $0.832^{* * *}$ & $0.623^{* * *}$ & $0.981^{* * * *}$ \\
$F$-statistics & $(0.030)$ & $(0.068)$ & $(0.070)$ \\
Partial $R^{2}$ & 776.76 & 84.84 & 196.83 \\
Observations & 0.743 & 0.500 & 0.600 \\
Number of pref & 329 & 141 & 188 \\
Year effect & 47 & 47 & 47 \\
\hline & Yes & Yes & Yes \\
\hline
\end{tabular}

Note: Figures in parentheses are standard errors.

***Significant at the 1 percent level.

**Significant at the 5 percent level.

*Significant at the 10 percent level.

cent decrease in the ratio of children old enough to receive compulsory education increases the per-student education costs by around 0.8 percent. According to the population projections by the National Institute of Population and Social Security Research of the Japanese government, the ratio of the population of children old enough to receive compulsory school attendance will decrease by 29.7 percent from 2005 to 2030 , and the ratio of the population of the elderly who are sixty-five years or above will increase by 57.4 in the same period. Consequently, the net effect of the demographic change will be a 10.2 percent decrease in the per-student public education costs: per-student education costs will be increased by 23.8 percent through the decrease in the number of children and will be decreased by 34.4 percent through the increase in the population of the elderly. 


\subsection{Why Did the Effects of Demographics on Public Education Change in the 1990s?}

What caused the change from no correlation in the 1980s to a negative relation in the 1990s in the effects of the ratio of the elderly on the perstudent compulsory education costs? Let us examine several possibilities.

First, the disposition of the elderly in Japan might have changed from altruistic to self-interested or from being short-term to long-term decision makers around the 1990s. However, the following question then arises: why did the preferences of the elderly change in the 1990s?

Second, the change in the voting rates might have affected the relationship between the ratio of the elderly and public education costs. Recently, voting rates have been decreasing in Japan. Moreover, the percentage of young voters has dropped, although that of the elderly is stable. Thus, the political power of the elderly has been strengthened more than expected as a result of the demographic change. This change in voting behavior by age group might have enabled the elderly to acquire political power and implement policies that are beneficial to them.

Third, the change in the household structure might cause the change in the effects of population aging on public education costs. It is expected that elderly people became self-interested and no longer focused on children and grandchildren because the percentage of the elderly living independently from their children increased, while the percentage of the elderly living with their children and grandchildren as extended family members decreased. The estimation results of Hoxby (1998) also indicate that the effects of aging on public education changed from positive in the early 1900s to negative in the 1990s. Poterba (1998) speculated that this reversal of the effects of population aging on public education costs was caused by the increase in the ratio of the elderly who lived independently. If the elderly have children or grandchildren old enough to receive compulsory education within the same household, they are interested in public education and understand its importance. However, they would prefer policies that are more directly beneficial to them than to public education if they live independently from their children.

Fourth, the change in the effects of the coefficient of the ratio of the elderly on public education costs might not be caused by the change in the preference of the elderly with regard to education. Rather, it might be caused by the change in the public finance system of local governments, as explained in section 6.3.1.

In Japan, the ratio of three-generation families has decreased, while the ratio of single-member families of the elderly has increased. These changes in the family structure might affect the attitudes of the elderly toward public education.

In this section, we analyze the effects of the change in the family structure 
Change of household structure (national average: \%)

\begin{tabular}{lcccc}
\hline & $\begin{array}{c}\text { Population } \\
\text { share of old }\end{array}$ & $\begin{array}{c}\text { Household share } \\
\text { of three-generation } \\
\text { family }\end{array}$ & $\begin{array}{c}\text { Household share } \\
\text { of nuclear family }\end{array}$ & $\begin{array}{c}\text { Household share } \\
\text { of elderly family }\end{array}$ \\
\hline 1975 & 9.05 & 21.99 & 67.48 & 5.92 \\
1980 & 10.25 & 18.68 & 58.21 & 5.84 \\
1985 & 11.56 & 17.82 & 57.95 & 7.46 \\
1990 & 13.58 & 15.95 & 57.72 & 9.68 \\
1995 & 16.31 & 13.80 & 57.08 & 12.33 \\
2000 & 19.15 & 11.41 & 57.26 & 15.27 \\
2005 & 21.79 & 9.45 & 57.11 & 18.41 \\
\hline
\end{tabular}

Source: "The Population Census" (Ministry of Internal Affairs and Communications).

on compulsory education. We used the ratios of three-generation families, nuclear families, and single-member families from the census as the explanatory variables of household structure. Table 6.6 presents the change in the ratios of the family structure variables. During the last three decades, the percentage of single-member families of the elderly has increased, while that of three-generation families has decreased, as shown in table 6.6. Thus, the Japanese elderly began to live independently from their children when they were old enough to receive compulsory education.

Table 6.7 provides the estimation results for the models, including the share of single-member households of the elderly as an explanatory variable to test the effect of the change in the living arrangements of the elderly on public education. Columns (1) to (3) show the results of the fixed effect models for the entire sample, the sample of the 1980s, and the sample of the 1990s, respectively. Columns (4) to (6) show the results of IV estimation for the same sample periods. The inclusion of the share of singlemember households as explanatory variables does not change the estimated coefficients of the population share of the elderly. To examine the effect of the living arrangement on the public educational spending, we use the other types of variables different from the previous estimation. The other types of variables, such as the share of elderly households or the share of households with their children living nearby, are obtained from the "National Livelihood Survey" conducted by the Health, Labor, and Welfare Ministry. ${ }^{6}$ The sample periods are from 1986 to 2004 because of data availability. The estimation results of regressions for several specifications are reported in table 6.8. Column (1) shows the benchmark result. Columns (2) to (4) show the results of adding the living arrangement variables. The negative coefficient not available because of the Hansin-Awaji earthquake. 


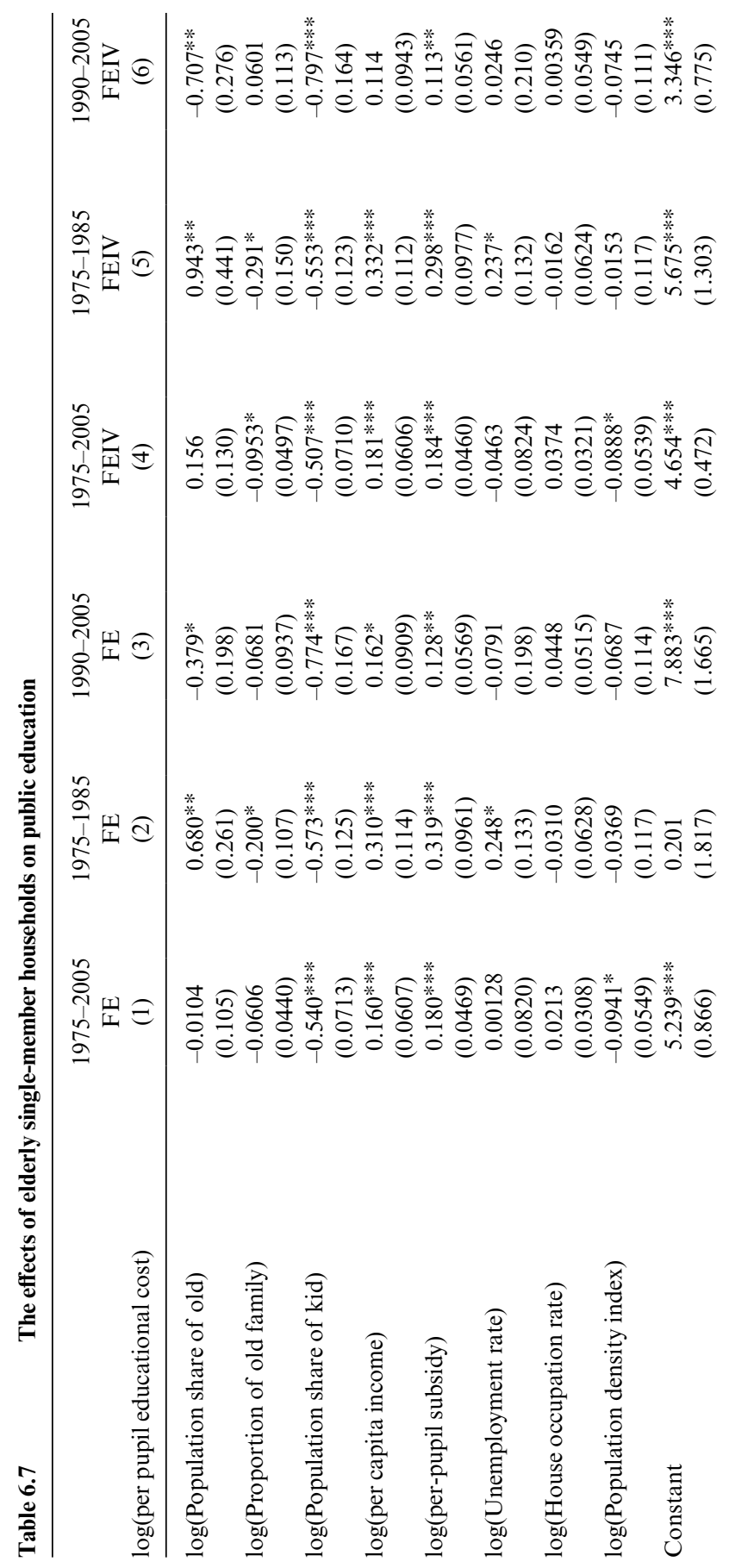




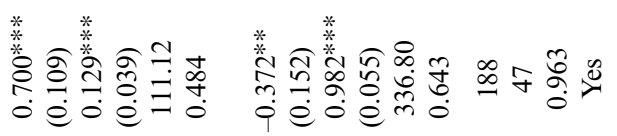

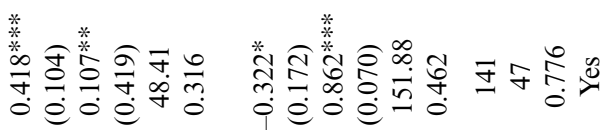

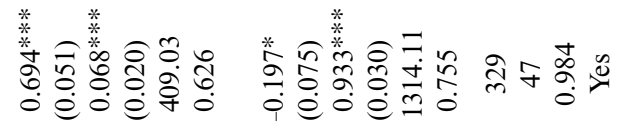

高

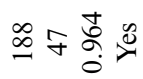

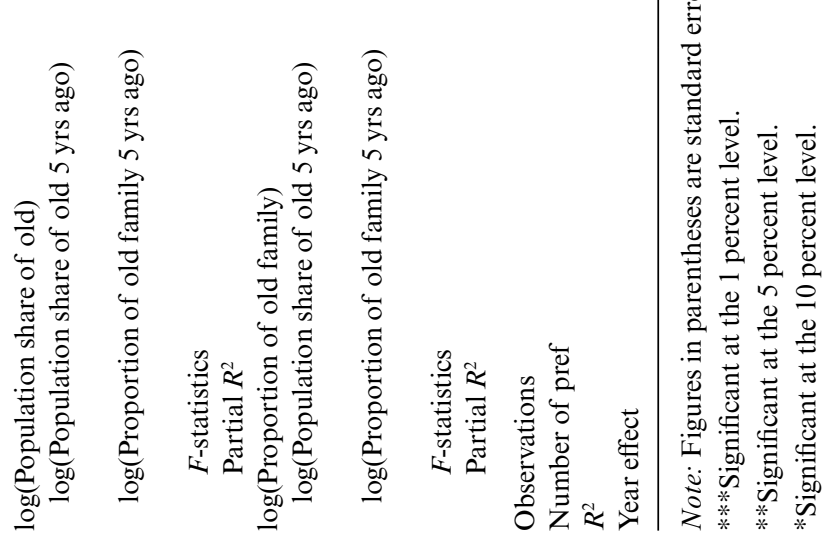

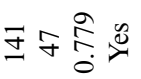

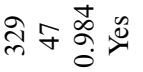


Table 6.8

The effects of living arrangements of elderly on public education costs (1986 to 2004)

\begin{tabular}{|c|c|c|c|c|}
\hline $\log ($ per pupil educational cost) & $\begin{array}{l}\mathrm{FE} \\
(1)\end{array}$ & $\begin{array}{l}\text { FE } \\
(2)\end{array}$ & $\begin{array}{l}\mathrm{FE} \\
(3)\end{array}$ & $\begin{array}{l}\text { FE } \\
(4)\end{array}$ \\
\hline $\log$ (Population share of old $)$ & $\begin{array}{l}-0.487 * * * \\
(0.0633)\end{array}$ & $\begin{array}{l}-0.480 * * * \\
(0.0683)\end{array}$ & $\begin{array}{l}-0.470 * * * \\
(0.0694)\end{array}$ & $\begin{array}{l}-0.486 * * * \\
(0.0699)\end{array}$ \\
\hline $\log$ (Share of elderly households) & & $\begin{array}{c}0.0332 \\
(0.0298)\end{array}$ & $\begin{array}{c}0.0608 \\
(0.0447)\end{array}$ & $\begin{array}{l}-0.115 \\
(0.222)\end{array}$ \\
\hline $\begin{array}{l}\log \text { (Share of elderly households without } \\
\text { children) }\end{array}$ & & $\begin{array}{l}-0.0340^{* *} \\
(0.0149)\end{array}$ & $\begin{array}{l}-0.0410^{* *} \\
(0.0172)\end{array}$ & \\
\hline $\begin{array}{l}\log \text { (Share of households with children living } \\
\text { nearby) }\end{array}$ & & & $\begin{array}{l}-0.0190 \\
(0.0230)\end{array}$ & $\begin{array}{c}0.0412 \\
(0.0723)\end{array}$ \\
\hline $\log$ (Share of households without children) & & & & $\begin{array}{r}0.0706 \\
(0.149)\end{array}$ \\
\hline $\log$ (Population share of kid) & $\begin{array}{l}-0.708 * * * \\
(0.0743)\end{array}$ & $\begin{array}{l}-0.733^{* * *} \\
(0.0748)\end{array}$ & $\begin{array}{l}-0.733^{* * *} \\
(0.0749)\end{array}$ & $\begin{array}{l}-0.715^{* * * *} \\
(0.0755)\end{array}$ \\
\hline $\log ($ per capita income $)$ & $\begin{array}{l}0.0711^{* *} \\
(0.0361)\end{array}$ & $\begin{array}{c}0.0680^{*} \\
(0.0361)\end{array}$ & $\begin{array}{r}0.0698^{*} \\
(0.0361)\end{array}$ & $\begin{array}{c}0.0699^{*} \\
(0.0365)\end{array}$ \\
\hline $\log$ (per-pupil subsidy) & $\begin{array}{l}0.167^{* * *} \\
(0.0636)\end{array}$ & $\begin{array}{l}0.155^{* *} \\
(0.0635)\end{array}$ & $\begin{array}{r}0.150^{* *} \\
(0.0637)\end{array}$ & $\begin{array}{c}0.164^{* *} \\
(0.0645)\end{array}$ \\
\hline Constant & $\begin{array}{l}7.745^{* * *} \\
(0.684)\end{array}$ & $\begin{array}{l}7.845^{* * *} \\
(0.683)\end{array}$ & $\begin{array}{l}7.807^{* * * *} \\
(0.685)\end{array}$ & $\begin{array}{l}7.867^{* * * *} \\
(0.724)\end{array}$ \\
\hline Observations & 328 & 328 & 328 & 328 \\
\hline Number of pref & 47 & 47 & 47 & 47 \\
\hline$R^{2}$ & 0.979 & 0.979 & 0.979 & 0.979 \\
\hline Year effect & Yes & Yes & Yes & Yes \\
\hline
\end{tabular}

Notes: Living arrangement variables such as share of elderly households are obtained from the National Livelihood Survey (Health, Labor, and Welfare Ministry). The National Livelihood Survey is conducted at intervals of three years. It is available from 1986. Total number of observation is 329 (= 47×7 waves), but the figure of Hyogo in 1994 is not available because of the Hansin-Awaji earthquake. Figures in parentheses are standard errors.

$* * *$ Significant at the 1 percent level.

**Significant at the 5 percent level.

*Significant at the 10 percent level.

of the share of the elderly does not change when the living arrangement variables are included in the explanatory variables.

The hypothesis that the change in the living arrangements of the elderly in Japan caused the change in the preference for public education among the elderly was not accepted.

We speculate that the change in the subsidy system for compulsory education from the national to the local governments affected the change in the estimation results between the 1980s and 1990s. From 1985, the subsidy from the national government for the salary of teachers has been gradually reduced. Thus, the burden of the local governments with regard to public education has been increased in the last two decades. This change is shown 
in table 6.5. Although the elasticity of the subsidy for per-student education costs was about 0.3 in the $1980 \mathrm{~s}$, it became about 0.1 in the $1990 \mathrm{~s}$.

As the discretionary power and the fiscal burden of the local governments with regard to compulsory education increased, the local governments began to be affected by political pressure from the elderly voters who were less supportive in terms of increasing the public education costs.

\subsection{Conclusion}

This chapter examined the effects of demographic change on compulsory education costs using prefectural panel data from 1975 to 2005 in Japan. If the elderly are self-interested and short-term decision makers, they would try to reduce government expenditure on compulsory education. On the other hand, the elderly would try to increase public education costs if they are altruistic or long-term decision makers.

Our estimation results indicate that the higher share of the elderly increased the expenditure on compulsory education per student by local governments in the 1980s; however, this relationship was reversed in the 1990s.

We did not find evidence that this change was caused by the change in the living arrangements of the elderly in Japan. Thus, we suspect that the change in the relationship between public education costs and population aging was caused by the changes in the fiscal system, which increased the discretionary power of the local governments in determining public education costs.

Three issues are pointed out for future research. First, we need a detailed analysis of the effects of the changes in the subsidy system on compulsory education and on the relationship between population aging and public education costs. Second, a municipal level analysis would be more useful since there are many more variations in both demographic and education costs. Third, the quality of education and demographic change should be analyzed directly. 


\section{Appendix}

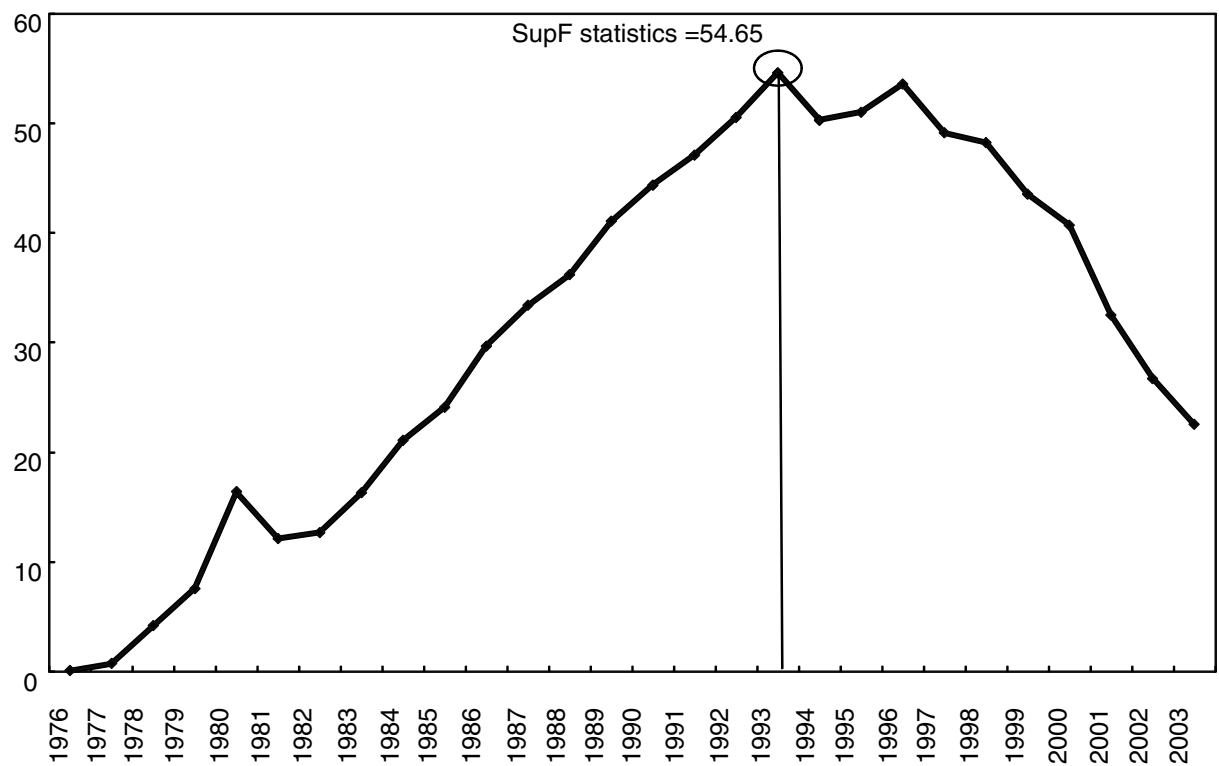

Fig. 6A.1 Test for structural change (SupF test)

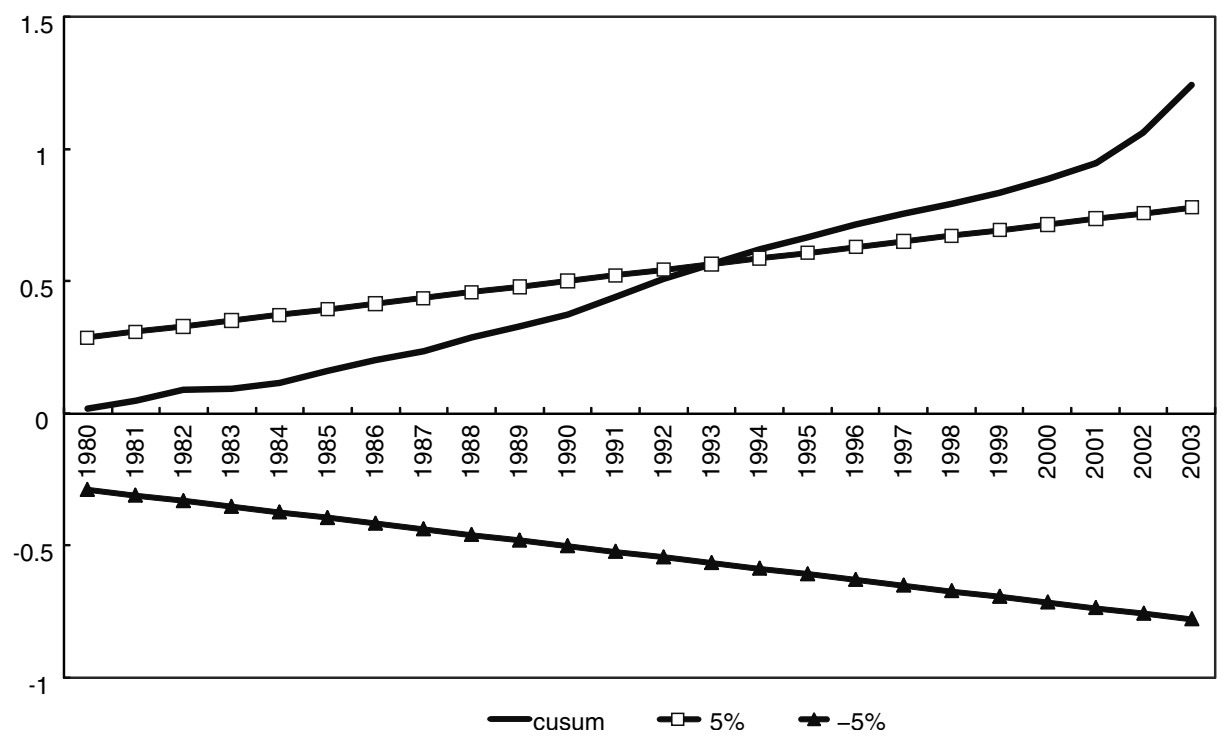

Fig. 6A.2 Test for structural change (CUSUM test) 


\section{References}

Brunner, E., and E. Balsodon. 2004. Intergenerational conflict and the political economy of school spending. Journal of Urban Economics 56 (2): 369-88.

Doi, T. 1998a. Empirics of the median voter hypothesis in Japan. Discussion Paper Series No. F-69, Institute of Social Science, University of Tokyo.

-1998b. New evidence on the median voter hypothesis in Japan. Discussion Paper Series No. F-72, Institute of Social Science, University of Tokyo.

Goldin, C., and L. F. Katz. 1998. The origins of state-level differences in the public provision of higher education: 1890-1940. American Economic Review 88 (2): 303-08.

Gradstein, M., M. Justman, and V. Meier. 2005. The political economy of education: Implication for growth and inequality. Cambridge, MA: MIT Press.

Grob, U., and S. C. Wolter. 2005. Demographic change and public education spending: A conflict between young and old? CESifo Working Paper no. 1555, October. Munich: Ifo Institute for Economic Research.

Harris, A. R., W. N. Evans, and R. M. Schwab. 2001. Education spending in an aging America. Journal of Public Economics 81 (3): 449-72.

Hoxby, C. M. 1998. How much does school spending depend on family income? The historical origins of current school finance dilemma. American Economic Review 88 (2): $309-14$.

Kariya, T. 2006. Change of equal opportunity in education. ASTEION no. 65. (In Japanese.)

Ladd, H. F., and S. E. Murry. 2001. Intergenerational conflict reconsidered: Country demographic structure and the demand for public education. Economics of Education Review 20:343-57.

Oberndorfer, U., and V. Steiner. 2006. Intergenerational conflict, partisan politics, and public higher education spending: Evidence from the German states. IZA Discussion Paper no. 2417 November. Institute for the Study of Labor.

Person, T., and G. Tabellini. 2000. Political economics: Explaining economic policy. Cambridge, MA: MIT Press.

Poterba, J. 1997. Demographic structure and the political economy of public education. Journal of Policy Analysis and Management 16 (1): 48-66.

1998. Demographic change, intergenerational linkage, and public education. American Economic Review 88 (2): 315-20.

Rubinfeld, D. L. 1977. Voting in a local school election: A micro analysis. Review of Economics and Statistics 59 (1): 30-42.

Sugimoto, Y., and M. Nakagawa. 2007. From duty to right: The role of public education in the transition to aging societies. ISER Discussion Paper no. 700. Institute of Social and Economic Research, Osaka University.

\section{Comment Dae Il Kim}

The authors of this chapter present quite important and interesting empirical findings. The share of the elderly population negatively affects the level of public educational expenditure in recent years in Japan, as was found 